\title{
Epidemiology of Japanese encephalitis: past, present, and future prospects
}

\author{
This article was published in the following Dove Press journal: \\ Therapeutics and Clinical Risk Management \\ 19 March 2015 \\ Number of times this article has been viewed
}

\author{
Huanyu Wang ${ }^{1,2}$ \\ Guodong Liang ${ }^{1,2}$
}

'State Key Laboratory for Infectious Disease Prevention and Control (SKLID), Department of Viral Encephalitis, Institute for Viral Disease Control and Prevention, Chinese Center for Disease Control and Prevention, Beijing People's Republic of China; ${ }^{2}$ Collaborative Innovation Center for Diagnosis and Treatment of Infectious Diseases, Hangzhou, People's Republic of China

Correspondence: Huanyu Wang State Key Laboratory for Infectious Disease Prevention and Control (SKLID), Department of Viral Encephalitis, Institute for Viral Disease Control and Prevention, Chinese Center for Disease Control and Prevention, 155\# Changping Qu Changbai Road, Beijing, People's Republic of China

Tel +86 1058900843

Fax +86 I0 58900840

Email rainoffall@yahoo.com

Guodong Liang

State Key Laboratory for Infectious

Disease Prevention and Control (SKLID),

Department of Viral Encephalitis, Institute for Viral Disease Control and Prevention, Chinese Center for Disease Control and Prevention, 155\# Changping Qu Changbai Road, Beijing, People's Republic of China

Tel +86 I0 58900838

Fax +86 I0 58900839

Email gdliang@hotmail.com

\begin{abstract}
Japanese encephalitis (JE) is one of severe viral encephalitis that affects individuals in Asia, western Pacific countries, and northern Australia. Although 67,900 JE cases have been estimated among 24 JE epidemic countries annually, only 10,426 have been reported in 2011. With the establishment of JE surveillance and vaccine use in some countries, the JE incidence rate has decreased; however, serious outbreaks still occur. Understanding JE epidemics and identifying the circulating JE virus genotypes will improve JE prevention and control. This review summarizes the current epidemiology data in these countries.
\end{abstract}

Keywords: Japanese encephalitis, Japanese encephalitis virus, acute encephalitis syndrome

\section{Introduction}

Japanese encephalitis (JE) is one of serious vector-borne viral encephalitis disease found worldwide, especially in Asian, the Western Pacific countries, and in northern Australia. ${ }^{1}$ Over 3 billion individuals live in JE epidemic and/or endemic countries. It is estimated that approximately $67,900 \mathrm{JE}$ cases have occurred annually in 24 countries, with only 10,426 cases reported in $2011 .^{2,3}$ The fatality rate in JE cases ranges from $20 \%-30 \%$, with neurologic or psychiatric sequelae observed in $30 \%-50 \%$ of survivors. ${ }^{3}$

JE is induced by infection with Japanese encephalitis virus (JEV), which belongs to the JEV serogroup in the genus Flavivirus, family Flaviviridae. ${ }^{4} \mathrm{JEV}$ has a singlestranded, positive-sense RNA genome of $\sim 11 \mathrm{~kb}$ in length. The JEV virion contains seven non-structural proteins (NS1, NS2A, NS2B, NS3, NS4A, NS4B, and NS5) and three structural proteins: nucleocapsid or core protein $(C)$, non-glycosylated membrane protein $(\mathrm{M})$, and glycosylated envelope protein $(\mathrm{E}) .^{5}$ The main JEV transmission vector is the $C x$. mosquito especially $C x$. tritaeniorhynchus, and the main vertebrate amplifying hosts are pigs and wading birds. ${ }^{6}$

\section{Epidemiology of JE Epidemiological patterns}

Two epidemiological patterns of JE are recognized: epidemic and endemic (Figure 1). ${ }^{6,7}$ Epidemic patterns observed mainly in northern areas (Bangladesh, Bhutan, People's Republic of China, Taiwan, Japan, South Korea, North Korea, Nepal, northern Vietnam, northern India, northern Thailand, Pakistan, and Russia) demonstrate typical seasonal characteristics with occasional outbreaks. Endemic patterns found in southern areas (Australia, Burma, Brunei Darussalam, Cambodia, Indonesia, Laos, Malaysia, Papua New Guinea (PNG), Philippines, Singapore, southern Vietnam, southern Thailand, southern India, Sri Lanka, and Timor-Leste) occur sporadically throughout the year. 


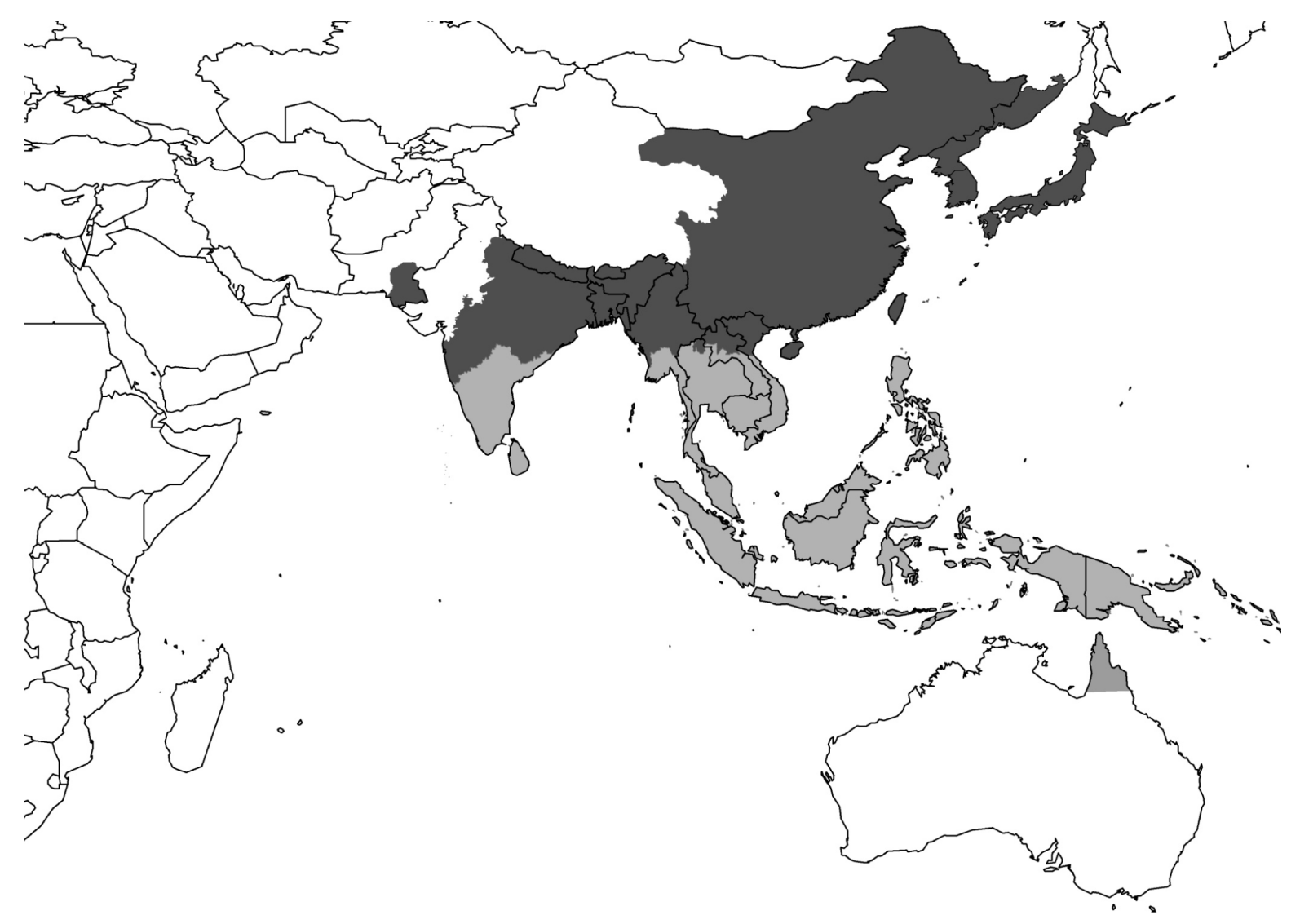

Figure I Global distribution of Japanese encephalitis (JE) infection countries and risk areas.

Notes: $\square$ Japanese encephalitis risk countries that the epidemiological pattern of JE is epidemic; $\square$ Japanese encephalitis risk countries that the epidemiological pattern of $\mathrm{JE}$ is endemic.

\section{Geographic distribution of JE}

The characteristics of JE epidemics among the 27 countries and regions have changed with adjustments in JE prevention and control measures. The characteristics of epidemic and endemic JE, the sort of vaccine, as well as the JEV genotypes in these areas are summarized below and in Table 1.

\section{Australia}

JE was first recognized in 1995 in an outbreak of three cases in the Torres Strait, Australia; two JEV isolates were obtained from the serum of two patients. ${ }^{89}$ Mosquito surveillance indicated that $C x$. annulirostris was the major vector, which was carried by the wind from New Guinea. ${ }^{9-13}$ Two additional JE cases were reported, including the first cases on mainland Australia. A serological survey in domestic pigs showed widespread JEV activity in north Queensland in 1998. ${ }^{14,15}$ Follow-up surveillance on pigs and mosquitoes indicated that the JE risk was not eliminated. ${ }^{16,17}$ The inactivated mouse brain-derived (MBD) JE vaccine was used exclusively on the residents of the Torres Strait Islands, as well as the people who lived or worked over 30 days on the Torres Strait islands during the rainy season. ${ }^{2}$

\section{Bangladesh}

First reported in 1977, a JE outbreak involving 22 cases with seven deaths was confirmed by serological testing. More than two-thirds of the patients were under 15 years old. However, serological surveillance revealed a low JE positive antibody rate after two years. ${ }^{18}$ In 2003-2005, a hospital-based surveillance of 492 patients at four sites revealed $20 \mathrm{JE}$ cases (4\%) with two deaths; all JE cases were from rural areas. The age distribution ranged from 1.5 months to 55 years, and $90 \%$ of the JE cases occurred during May-October, with nearly half in October. ${ }^{19}$ It is estimated that the JE incidence rate was 0.6-2.7 per 100,000 in Chittagong and Rajshahi. ${ }^{20}$

\section{Bhutan and Brunei Darussalam}

Little is known about JE epidemiology in this region.

\section{Myanmar (Burma)}

A serological survey proved the existence of JE in Burma in 1968. A JE outbreak was first reported in 1974 in Shan State in which five cases and four deaths were reported; 42 cases and 32 deaths were reported in the following year. 


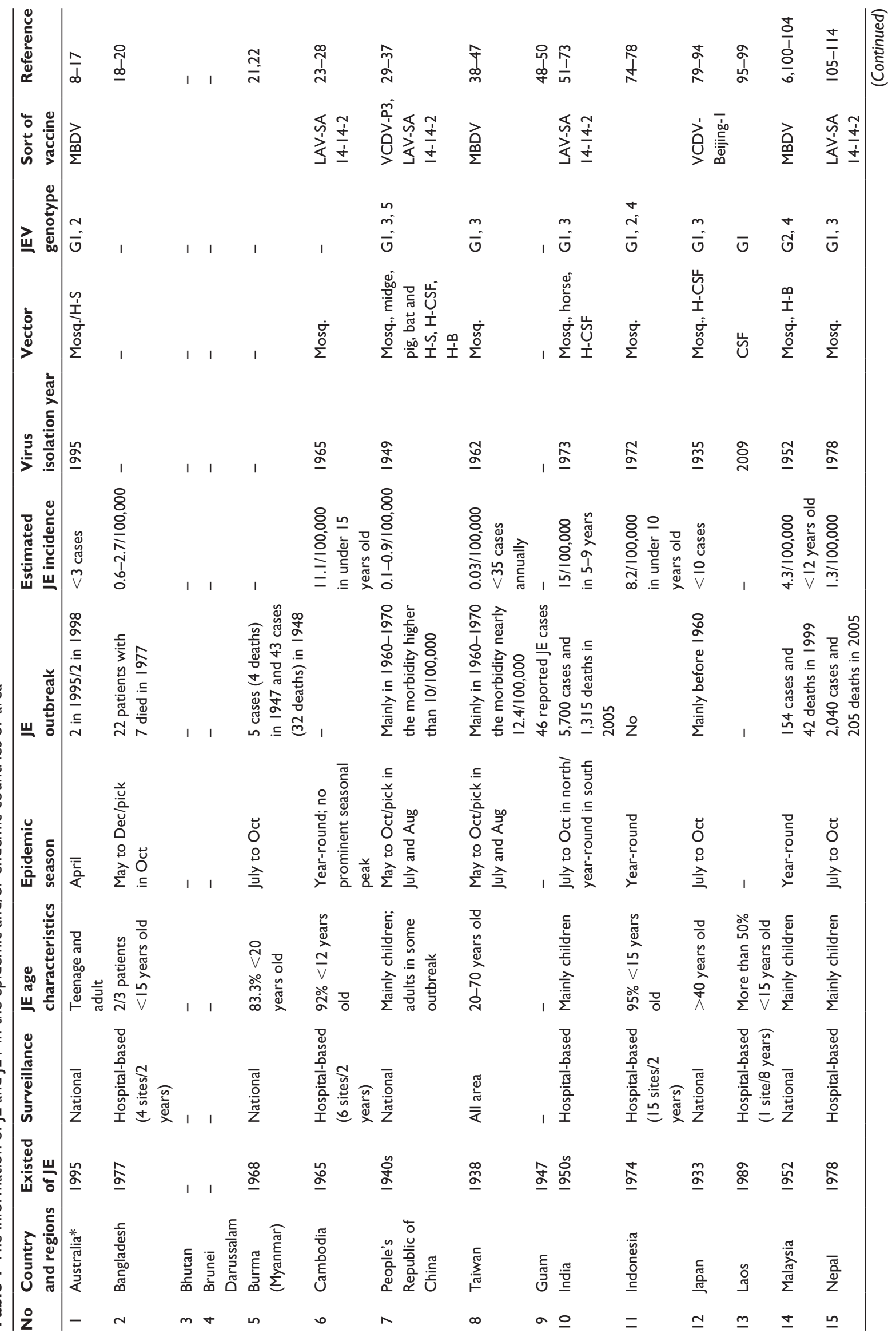




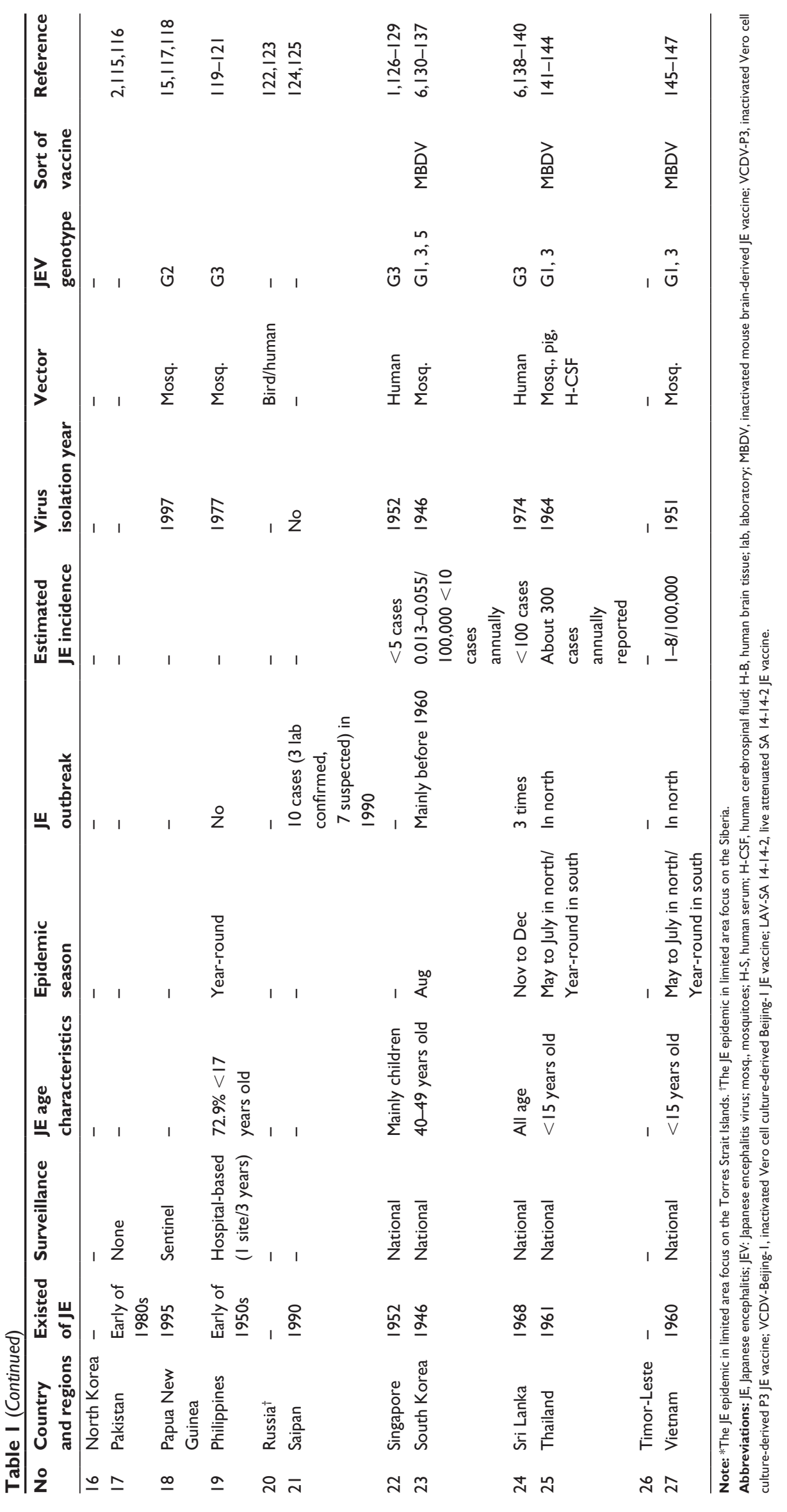


All cases occurred in July-October, and $83.3 \%$ of the patients were under 20 years old. ${ }^{21}$ The subsequent investigation showed that $C x$. tritaeniorhynchus was likely to have been the main vector, and the JE antibody positive rates were $81.5 \%$ and $42 \%$ in domestic animal and human populations, respectively. ${ }^{21}$ Another serological survey confirmed the prevalence of JEV infections in northwest Burma in a location distant from the JE outbreak in $1978 .^{22}$

\section{Cambodia}

JEV was first isolated from mosquitoes in 1965. Existing JE data were from several sentinel hospitals, with no national JE epidemiological data available. Among 50 pediatric clinical encephalitis cases diagnosed in the National Pediatric Hospital in Phnom Penh from July 1996 to September 1998, JE was confirmed in nine (18\%) patients, all of whom were under 10 years of age. ${ }^{23}$ In another surveillance performed by Takeo Provincial Hospital from October 1999 to September $2000,31 \%$ of the JE patients were under 15 years. ${ }^{24}$ Subsequently, two years of sentinel surveillance performed in six hospitals revealed that $95 \%$ of JE patients were under 12 years of age, and cases occurred throughout the year with no prominent seasonal peak. The estimated incidence of JE was 11.1 per 100,000 in children under 15 years of age. ${ }^{25}$ The extent of disability after JE resulted in $11 \%$ with severe sequelae. ${ }^{26} \mathrm{~A}$ study assessing JEV infection in pigs in eight provinces showed that pigs older than 6 months had high rates of JEV infection, suggesting that human JE disease also had the potential for high prevalence. ${ }^{27}$ After a cost and effectiveness analysis for the JE vaccine, the live attenuated SA 14-14-2 JE vaccine (LAV-SA 14-14-2) was used in the routine immunization strategy in Cambodia. ${ }^{2,28}$

\section{People's Repulic of China}

JE was first reported in the 1940s, and became the main cause of viral encephalitis in the People's Republic of China. The JE case reporting system has been mandated by law since $1951 .{ }^{29,30}$ The morbidity due to JE was 10-15 per 100,000 in 1960-1979, which reached the highest level (20.92 per 100,000) in 1971. The seasonal distribution of JE in the People's Republic of China is from June to October, with a peak in July and August. Children under 15 years of age constitute the majority of JE cases. ${ }^{29}$ Use of the MBD JE vaccine (P3 strain) began in the late 1970s, and the LAV-SA 14-14-2 was introduced in 1989. The reported cases of JE decreased dramatically from 10,308 in 1996 to 2541 in 2010. ${ }^{29,30}$ However, adult JE cases and outbreaks have been reported. ${ }^{31}$ Since 2008, JE immunization has been included in the national immunization program using the
LAV-SA 14-14-2 in 28 Chinese provinces, excluding Qinghai, Xinjiang, and Tibet. ${ }^{32}$ Tibet is a traditionally non-epidemic area in the People's Republic of China; however, JEV was isolated from Cx. tritaeniorhynchus in Linzhi, Tibet in 2009. In the same region, the JEV antibody was also tested in pig and human serum. ${ }^{33-35}$ A laboratory for JE surveillance of hospital-reported encephalitis cases was later set up in that area. In history, JE cases were mainly clinically reported. A survey based on the laboratory testing of the hospital-reported JE cases in Guizhou in 2006 showed nearly $87.6 \%$ of the reported clinical JE cases were laboratory confirmed and the high number of JE cases was mainly reported in county hospitals. ${ }^{36}$ Acute meningitis and encephalitis syndrome (AMES) surveillance in four prefectures in the People's Republic of China during 2006-2008 indicated that the adjusted estimate of JE incidence was three to ten times higher than that reported previously. ${ }^{37}$ The JE lab-net were set up in 2011 and with the improved JE surveillance system in the People's Republic of China, more than $90 \%$ of reported JE cases have been diagnosed by laboratory testing.

\section{Republic of China (Taiwan)}

"Summer encephalitis" was first documented in 1931; however, JEV isolation and serological evidence for the disease was not obtained until 1938. ${ }^{38-40}$ A JE vaccination campaign in infants and new school children was launched in 1968, and the complete JE immunization strategy was adjusted to include a total of four doses of MBD JE vaccine. ${ }^{40-42}$ At the same time, a live attenuated JE vaccine ( $\mathrm{M}$ strain) was also used to protect swine against stillbirths in Taiwan. ${ }^{43}$ The incidence rate of confirmed JE cases decreased significantly from 2.05 per 100,000 in 1967 to 0.03 per 100,000 in $1997 .^{40}$ The number of annual confirmed JE cases decreased dramatically from 35 cases in 2000 to only 20 in $2007 .{ }^{44}$ The epidemic season appeared from May to October, with a sharp peak in July and August. ${ }^{38-40,44}$ The age distribution shifted from mainly children to adults, with nearly $90 \%$ of laboratory-confirmed JE cases older than 20 years (range, 20-70 years). ${ }^{40,44}$ Currently, JE is a disease found predominantly in adults living in eastern, central, and southern Taiwan, ie, in regions with more livestock breeding and agricultural industry. ${ }^{44}$ Mosquito surveillance showed that $C x$. tritaeniorhynchus and $C x$. annulus were the most important JEV vectors to human and domestic animals. Cx. fuscocephala showed an overwhelming preference for the water buffalo, documented to be involved in JEV transmission in Taiwan. ${ }^{45-47}$

\section{Guam}

Although there is no evidence for any encephalitis in Guam, a JE outbreak in the Pacific islands occurred with a 
total of 46 clinical JE cases reported from October 1947 to April 1948. ${ }^{48,49}$ The mosquito survey showed that the $C x$. annulirostris marianae was a suspected vector during this outbreak. ${ }^{50}$

\section{India}

JE was first recognized via a serological survey in the 1950s. ${ }^{51-53}$ The first JE outbreak was reported in West Bengal in 1973, followed by reports in southern, eastern, and western states. ${ }^{54-58} \mathrm{JE}$ was first reported in Uttar Pradesh, the main JE epidemic area in the northern state of India in $1978 .{ }^{59}$ After that, a severe outbreak of JE occurred with 5,700 cases and 1,315 deaths in Uttar Pradesh state in $2005 .^{60,61}$ The clinical features of the cases were severe, and the in-hospital mortality was $34 \%$ in one hospital. ${ }^{62}$ Hospital-based acute encephalitis syndrome (AES) surveillance in north and northeast India showed that $\sim 25 \%$ of cases were positive for JE, which were prevalent mainly in children. ${ }^{63-65}$ The estimated JE incidence rate was 15 per 100,000 in 5-9-year-olds in Tamil Nadu, a state in southern India. ${ }^{66}$ The JEV infection rate reached as high as $70.7 \%$ of the cases. ${ }^{67}$ Laboratory tests confirmed that the JE cases occurred throughout the year, with more cases in the rainy season. ${ }^{68,69}$ A routine program was implemented in this JE epidemic area starting from 2006 using the LAV-SA 14-14-2. The $C x$. vishnui subgroup, and the $C x$. tritaeniorhynchus, Cx. seudovishnui and Anopheles subpictus, were the main mosquito vectors and secondary vectors in India. ${ }^{70-72}$ The minimum infection rate of JEV in mosquito remained as low as 0.8 annually from 1996 to $2004 .^{73}$

\section{Indonesia}

The first serologically confirmed JE cases were reported in 1996. ${ }^{74}$ Subsequently, hospital-based surveillance in Bali from 2001-2003 showed a total of 86 laboratory confirmed (with 4 probable) JE cases in 239 pediatric patients. The estimated JE incidence rate was 8.2 per 100,000 in children under 10 years of age. The JE cases occurred throughout the year, but mainly in the rainy season. ${ }^{75}$ A sentinel surveillance involving 15 hospitals in six provinces from 2005-2006 further confirmed the presence of JE cases in all provinces throughout the year, with $95 \%$ of cases occurring in children under 10 years of age. ${ }^{76}$ A survey of JEV antibodies in pigs showed that the antibody positive rate in Bali was higher than that in East Java, indicating that exposure to JEV infection and JEV transmission in nature were more active in Bali than in East Java. ${ }^{77,78} \mathrm{JEV}$ was first isolated from $C x$. tritaeniorhynchus in $1972 .^{76}$

\section{Japan}

After experiencing a serious summer encephalitis, Japan implemented the National Epidemiological Surveillance of Vaccine Preventable Diseases in 1965. The comprehensive surveillance included laboratory confirmation of reported JE cases, serological survey on JEV antibodies in the population, and a sentinel survey of JEV seroconversion rates in pig. ${ }^{79}$ The inactivated MBD JE vaccine using the Nakayama strain was distributed widely in $1967 .^{80}$ Subsequently, the annual number of JE cases decreased from more than 1,000 to 90 in 1991, and less than ten cases after that. All cases were reported from July to November. The age distribution changed from children to adults, with $78 \%$ of cases over 40 years old; $51 \%$ had records showing the lack of JE vaccinations. ${ }^{79}$ Although the numbers of JE cases were low, unexpected outbreaks still occurred. ${ }^{81,82}$ Inactivated Vero cell-derived JE vaccine produced with the Beijing-1 strain was used after $2005 .{ }^{83}$ The JEV NS1 antibody-based testing method was used as a marker to test the JEV natural infection rate, as the NS1 protein was not expressed after inoculation with the inactive vaccine. A survey on natural infection of JEV in humans and horses indicated that JE remains prevalent in Japan. ${ }^{80,84-89}$ CX. tritaeniorhynchus is the main vector in Japan..$^{90}$ Serological surveillance on JEV was performed in various animals including raccoons, raccoon dogs, wild boars, and horses. The results suggested that JEV was prevalent in wild animals and they may be potential sentinels to estimate JEV infection risk. ${ }^{91-94}$

\section{Laos}

The first reported cases of JE were described in 1990. A seroepidemiological study of JE in the Vientiane and Khammouane provinces showed that the JE antibody positive rate increased with age, reaching over $50 \%$ by $31-40$ years of age. ${ }^{95}$ A separate serological investigation in Khammouane province further proved the JE epidemic, with $1.3 \%$ positivity to JEV. ${ }^{96}$ A large-scale serosurvey for flavivirus including the dengue virus (DENV) and JEV was conducted in Vientiane, the capital of Laos, which contains $5 \%$ of the national population. This study indicated that urbanization affected the risk of virus infection. ${ }^{97} \mathrm{~A}$ hospital investigation from 2001 to 2008 showed a 10.1\% JE positive rate in AES and meningitis cases, with more than half of the JE cases under 15 years of age..$^{98}$ The first JEV was isolated from human blood in 2009, which belonged to genotype $1 .{ }^{99}$

\section{Malaysia}

Although information is scarce regarding the national JE epidemic in Malaysia, three JE outbreaks were recorded in 
1974, 1988, and 1999, with 154 reported JE cases (42 laboratory confirmed cases) and 56 deaths in the 1999 outbreak. Most of the patients were adult males who worked on pig farms. ${ }^{100,101}$ The MBD JE vaccine was introduced to children under 15 years of age in July 2001. According to a hospitalbased surveillance study focused on cases in Sarawak, the estimated JE incidence rate decreased from 9.8 to 4.3 cases per 100,000 children under 12 years of age. ${ }^{101-103} \mathrm{JEV}$ isolation from mosquitoes indicated that the main vectors were Cx. tritaeniorhynchus and Cx. gelidus, which breed primarily in rice fields. ${ }^{6}$ However, infection experiments suggested that $C x$. sitiens also had the capacity to transmit JEV in Peninsular Malaysia. ${ }^{104}$

\section{Nepal}

JE cases were first reported in 1978 in the Terai districts near India. ${ }^{105} \mathrm{JE}$ was a seasonal disease epidemic from July to October and the incidence rate decreased with altitude, showing higher rates in the south and lower rates in the northern mountains; however, the JE is still epidemic in the mountainous altitude. ${ }^{106}$ Four western Terai districts had significantly higher JE incidence rates than the other areas in Nepal. ${ }^{107,108}$ The laboratory-based surveillance of JE spanned from mid-2004 to 2010 and covered 126 hospitals in the country. A total of 2,040 JE cases including 205 deaths were reported from 2005 to 2010 after mass immunization in $2006 .{ }^{109}$ The JE incidence rate decreased to 1.3 per 100,000 after the JE immunization campaign. ${ }^{110}$ A routine program was implemented in this JE epidemic area starting from 2006 using the LAV-SA 14-14-2, followed by mass vaccination campaigns conducted in 23 districts with high JE epidemic area. ${ }^{110}$ Pigs in Terai, the lower border district, were vaccinated with live attenuated virus in 2001. JEV Serological data in pig indicated a serious risk for farmers, residents, and travelers. ${ }^{11-114}$

\section{North Korea}

Little is known about JE epidemiology in North Korea.

\section{Pakistan}

JE was confirmed by a seroepidemiological survey in the early 1980s in Pakistan. ${ }^{115}$ An acute encephalitis case was further confirmed during the JE epidemic in 1992 by molecular diagnosis using reverse transcriptionpolymerase chain reaction (RT-PCR) for JEV from cerebrospinal fluid (CSF). ${ }^{116}$ No national JE epidemiology information is available due to the lack of a surveillance $\operatorname{program}^{2}$

\section{Papua New Guinea (PNG)}

A JE outbreak had been a concern in the island between Papua New Guinea and Australia. JEVs were isolated from mosquitoes, and clinical cases were reported in the west province. In 2004, serological testing confirmed JE in a 66-year-old male from Port Moresby. ${ }^{15,117,118}$

\section{Philippines}

JE was first recorded in the early 1950s, and JEV was first isolated from mosquitoes in $1977 .{ }^{119}$ A serological study on clinical viral encephalitis cases revealed that $85.2 \%$ of JE cases were under 15 years old, and occurred mainly in February-September. ${ }^{120}$ In 2002-2005, a total of 614 CSF specimens were tested by IgM-capture enzyme-linked immunosorbent assay (ELISA), of which $11.7 \%$ were positive. Laboratory-confirmed JE cases were reported each year in individuals ranging from 2 to 77 years, however, $72.9 \%$ were under 17 years of age. JE cases occurred year-round, and mainly in the rainy season. ${ }^{121}$

\section{Russia}

The JE epidemic area was limited to the eastern coastal area of Siberia. JEV isolates were obtained from blood in migratory birds ${ }^{122}$ and human brain; ${ }^{123}$ however, the genotype was not clear due to lack of viral sequences.

\section{Saipan}

An outbreak of JE occurred in Saipan in October 1990. Ten cases (three laboratory-confirmed and seven probable) were identified in a human population of approximately 40,000. A community serosurvey showed that the neutralizing antibody of JEV was positive in lifelong Saipan residents in 1991, but negative in 1984. An animal serosurvey showed positive JEV antibody in 96\% swine, an important amplifying host of JEV when epidemics occur in ducks, dogs, and goats. ${ }^{124}$ No virus was isolated from mosquitoes. Cx. tritaeniorhynchus, an abundant and widely distributed species, is the first recorded in Saipan. ${ }^{125}$

\section{Singapore}

JE cases were first reported in $1952 .{ }^{1}$ Approximately $100 \mathrm{JE}$ cases were reported in the 1970s and early 1980s, and a dozen were reported during 1985-1992. ${ }^{126,127}$ The incidence of JE decreased dramatically in Singapore after pig farming was completely eliminated in 1992, with six reported JE cases from 1991-2005. ${ }^{128}$ However, seroepidemiological data on wild pigs and other local animals indicate that JEV is still circulating in nature, and the risk of JEV infection persists. ${ }^{126,127} \mathrm{JEV}$ isolates were obtained from mosquitoes and human blood. ${ }^{129}$ 


\section{South Korea}

A human JE case was first confirmed in $1946,{ }^{130}$ which was included in the national surveillance system in $1949 .{ }^{131}$ Before 1983, hundreds to thousands of JE cases were reported. ${ }^{6}$ The MBD JE vaccine was first administered to children in 1971, and the mass vaccination program started during a large outbreak in 1983. ${ }^{131}$ The JE incidence rate decreased to $0.013-0.055$ per 100,000 (about ten cases reported annually), with affected individuals in the age range of 40-49 years. The largest epidemic appeared in August. ${ }^{131}$ Mosquito surveillance showed that the $C x$. tritaeniorhynchus first appeared in June, were trapped in large numbers from mid-August to early September, then significantly decreased in early October. ${ }^{132,133}$ With the decline in JE cases, the serological surveillance on JEV in potential animals has been strengthened. The incidence of JEV was $51.3 \%$ in domestic cattle, ${ }^{134} 12.1 \%$ in goat, ${ }^{135} 49.7 \%$ in horses, ${ }^{136}$ and $86.7 \%$ in wild bird. ${ }^{137}$ At present, the most important public health problem is how to issue JE protection in adults who live in an urban or suburban environment with a strong immunization program in children.

\section{Sri Lanka}

The presence of JE was recorded in 1968, and the first JE outbreak was reported in $1971 .{ }^{138}$ Subsequently, three major outbreaks were reported in 1985-1987, ${ }^{6}$ with hundreds of JE cases occurred during the fall. Comparing epidemic (1987) and non-epidemic (1988) years, the difference can be explained by the abundance of major mosquitoes $(C x$. tritaeniorhynchus and Cx. gelidus) and virus infection rate. ${ }^{139}$ Immunization was launched in Sri Lanka in 1988 using two kinds of JE vaccines: the MBD JE vaccine and the live attenuated SA14-14-2 JE vaccine (LAJEV); however, the country's immunization program selected only the inactivated vaccine. ${ }^{138,140} \mathrm{JEV}$ was first isolated in $1974 .{ }^{139}$

\section{Thailand}

Serological testing identified the JEV antibody in 1961. Records for all types of encephalitis were included in the routine disease surveillance system in Thailand. JE was epidemic with high incidence and significant seasonal characteristics that occurred from May to September, with a peak in June or July, in the northern and northeast region. Endemic and sporadic cases were reported in the central and southern area. A total of 1500-2500 encephalitis cases were reported annually from the 1970s-1980s, which decreased to 297-418 per year from 2002-2008. ${ }^{141-143}$ A hospitalbased survey found that $74 \%$ and $15 \%$ laboratory-confirmed
JE cases were under 15 years of age in 1987 and 2003, respectively. ${ }^{142,143}$ The MBD JE vaccine was introduced into the Thai National Immunization Program (NIP) in 1990. ${ }^{144}$ Cx. tritaeniorhynchus, Cx. gelidus and Cx. fuscocephala were the main vectors of JE in Thailand. ${ }^{142}$

\section{Timor-Leste}

Little is known about JE epidemiology in this country.

\section{Vietnam}

Viral encephalitis (including JE) has been reported in the national surveillance system in Vietnam. The highest estimated JE incidence rate was 22 per 100,000 in the 1960s, which decreased to $1-8$ per 100,000 individuals. The highest incidence rates were reported in the provinces near the Red River delta region in the north and the Mekong River delta region in the south. MBD JE vaccine was introduced in 12 high-risk districts in the northern region in 1- to 5-yearold children in 1997, and expanded to $65 \%$ of districts in Vietnam. ${ }^{145} \mathrm{JE}$ displayed an obvious age distribution and seasonal pattern in the northern region. Over $65 \%$ of AES cases under 18 years old were laboratory-confirmed JE cases, mainly from May-July. On the other hand, sporadic JE cases were reported throughout the year. ${ }^{146,147}$ JEV was first isolated in $1951 .^{145}$

\section{JEV genotype distribution}

The prototype Nakayama JEV strain was isolated from a post-mortem human brain in Tokyo, Japan, in $1935 .{ }^{148} \mathrm{Sub}-$ sequently, more JEV isolates were obtained from mosquitoes, pigs, humans, bats, midges, and wild birds worldwide. Phylogenetic analysis of JEV strains revealed that JEVs can be divided into four genotypes using the $p r M$ gene $^{149,150}$ and five genotypes according to the E gene and full length genome. ${ }^{151,152}$ The most recent common ancestor (TMRCA) analysis according to the complete genomic sequences of JEV isolated from human, various mosquitoes, midges, pigs, and bats, indicates that the JEV genome appeared 1695 years ago. Genotype $1 \mathrm{JEV}$ expanded in epidemic areas over the last 30 years, and an alternative genotype 3 became a domestic pathogen. ${ }^{153,154}$

Three JEV genotypes (G1, 3, and 5) from mosquitoes, bats, midge, and humans were isolated in Mainland China, ${ }^{31,34,155-158}$ and two JEV genotypes (G1 and 3) were isolated in Taiwan. The JEV isolates from mosquitoes, pigs, bird, and human belonged to G3 before 2008, after which G1 was the only isolate from mosquitoes. ${ }^{159-161}$ Two JEV genotypes (G1 and 3) had been isolated in Japan. The JEV 
isolates from mosquitoes, pigs, and human belonged to G3 before 1992, co-circulated from 1993-1994, after which G1 dominated. JEV G1 was isolated from mosquitoes and horses, and G1 sequences were found in wild boar and a meningitis patient; however, G3 was also isolated or identified by RT-PCR in JE cases. ${ }^{81,85,162-174}$ Three JEV genotypes (G1, 3 and 5) were isolated or sequenced in South Korea. G3 was dominant before 1993; G1 and G3 co-circulated in 1993-1994, after which G1 was the only genotype isolated from mosquitoes and pig. ${ }^{130,175-178}$

India, Nepal, Thailand, and Vietnam also had G1 and G3 genotypes, and G1 became the dominant genotype in this area. ${ }^{179}$ In India, phylogenetic analysis of the JEVs isolated from human CSF in 2009-2010 showed that G1 and G3 were co-circulating. ${ }^{180,181}$ However, the equine isolates also belonged to the G3, similar to the old strain. ${ }^{182,183}$ In Vietnam, the JEV isolated from mosquitoes, pigs, and human belonged to G3 before 2001, after which G1 was the only genotype isolated from mosquitoes. ${ }^{184-187} \mathrm{JEV}$ G1 was isolated from mosquitoes from 2000-2004 in Australia, ${ }^{16}$ where the G2 genotype was isolated from mosquito and patients, ${ }^{9,10}$ and also in PNG. ${ }^{117}$

All parental strains currently used for JEV vaccines (SA14 and Beijing-1 from the People's Republic of China, and Nakayama from Japan) are derived from JEV G3. Although five genotypes of JEV are found in nature, only one JEV serotype occurs naturally. In theory, the vaccine that is currently in use could protect against the epidemic JEV. The study indicated that the vaccine currently used prevents the G1 and G3 JEV infections prevalent in the People's Republic of China. ${ }^{188}$ At present, the licensed JE vaccines used in different countries include inactivated MBD (Nakayama and Beijing-1), inactivated Vero cell-based (Beijing-1, P-3, SA 14-14-2, Kolar strain-JEV 821564XY), live attenuated vaccine (SA14-14-2) from Chengdu Institute of Biological Products, and the chimeric live attenuated SA14-14-2 vaccine. The live attenuated SA14-14-2 vaccine is the first Chinese vaccine to have its safety and quality endorsed by the World Health Organization (WHO) for use with children. The efficiency of the present JE vaccine in eliciting protective neutralizing antibodies against different JEV strains needs to be evaluated.

\section{Summary and future prospects}

According to the current epidemic/endemic characteristics of $\mathrm{JE}$, the disease surveillance and vaccination strategies in these countries and regions could be divided into four levels.

Group 1: Japan, South Korea, and Republic of China (Taiwan) have reported JE epidemics; however, these countries conducted complete surveillance and JE immunization programs, resulting in $<30$ reported JE cases annually. The characteristics of the JE epidemics were analyzed and JE control measures have continued. The main public health problem, prevention and future control, will focus on adult JE cases following long-term mass JE immunization.

Group 2: Cambodia, People's Republic of China, India, Malaysia, Nepal, Sri Lanka, Thailand, and Vietnam, have reported JE epidemics, endemics and/or outbreaks. National or sentinel (hospital-based) surveillance programs were established, and JE vaccines were used in national or sub-national areas (in high-risk area). The JE cases reported worldwide are mainly from these countries, especially India and the People's Republic of China, which account for $95 \%$ of all cases. JE prevention and control are the main issues for global JE control. The following comprehensive measures should be adopted: 1) expansion of the surveillance system to include i) laboratory confirmation of JE and AES cases to understand the actual JE incidence, ii) virus isolation in mosquitoes and JE cases to grasp the molecular characteristics and mutation of the JEVs, iii) seroconversion rates in amplifying vectors (sentinel pigs or wild birds) nationwide, iv) assessment of the prevalence of JE antibodies in the general population. 2) Incorporation of the $\mathrm{JE}$ vaccine into routine immunization programs in children. Japan's success has demonstrated the $\mathrm{JE}$ vaccine as the most effective measure to reduce JE incidence. 3) Establishment of different pig breeding patterns by moving large-scale pig farms away from rice paddies. This measure will greatly reduce the chance of people becoming infected with JE; however, it is closely related to the economic level of the country. 4) Mosquito vector control, improvement in the living environment, and health education are important, especially during a JE outbreak.

Group 3: Bangladesh, Bhutan, Brunei Darussalam, Burma (Myanmar), Indonesia, Laos, North Korea, Pakistan, PNG, Philippines, and Timor-Leste have no known established sentinel JE surveillance systems, and no JE immunization programs. Future national surveillance programs should focus on JE cases to understand the disease burden, although these countries report fewer than 100 JE cases.

Group 4: Australia (risk area), Guam, Russia (Siberia), Singapore, and Saipan have reported fewer than three JE cases annually. Therefore, maintenance of the existing surveillance systems and developing immunization strategies as a one-time campaign in the target population are suggested.

Though JE is highly distributed, outbreaks still occur in epidemic areas. Other than the present conventional practices 
(mosquito control, health education propaganda, etc), emergency vaccination campaigns are currently the most effective measures against outbreaks.

\section{Conclusion}

Although JE remains a prominent public health problem in Asia, the reported cases are decreasing due to JE immunization (especially in the People's Republic of China and India), agricultural pattern changes, urbanization, and improved living conditions. As JEV will likely remain in nature and the risk of JE will persist, it is important to implement strategies that strengthen JE surveillance systems in order to understand the disease burden and apply vaccination protocols in national childhood immunization programs.

\section{Acknowledgments}

This work is supported by grants from China Mega-Project for Infectious Disease (2012ZX10004215, 2013ZX10004101), National Natural Science Foundation of China (81290342), The Ministry of Science and Technology, China (2011CB504702), and Development Grant of State Key Laboratory for Infectious Disease Prevention and Control (2014SKLID103). The funders had no role in study design, data collection and analysis, decision to publish, or preparation of the manuscript.

\section{Disclosure}

The authors report no conflicts of interest in this work.

\section{References}

1. Erlanger TE, Weiss S, Keiser J, Utzinger J, Wiedenmayer K. Past, present, and future of Japanese encephalitis. Emerg Infect Dis. 2009;15(1): $1-7$.

2. Japanese encephalitis surveillance and immunization - Asia and the Western pacific, 2012. MMWR Morb Mortal Wkly Rep. 2013;62(33): 658-662.

3. Campbell GL, Hills SL, Fischer M, et al. Estimated global incidence of Japanese encephalitis: a systematic review. Bull World Health Organ. 2011;89(10):766-774, 774A.

4. Solomon T. Flavivirus encephalitis. $N$ Engl J Med. 2004;351(4): 370-378.

5. Chambers TJ, Hahn CS, Galler R, Rice CM. Flavivirus genome organization, expression, and replication. Annu Rev Microbiol. 1990;44: 649-688.

6. Vaughn DW, Hoke CJ. The epidemiology of Japanese encephalitis: prospects for prevention. Epidemiol Rev. 1992;14:197-221.

7. Solomon T, Dung NM, Kneen R, Gainsborough M, Vaughn DW, Khanh VT. Japanese encephalitis. J Neurol Neurosurg Psychiatry. 2000;68(4):405-415.

8. Japanese encephalitis acquired in Australia. Emerg Infect Dis. 1995; 1(3): 102 .

9. Hanna JN, Ritchie SA, Phillips DA, et al. An outbreak of Japanese encephalitis in the Torres Strait, Australia, 1995. Med J Aust. 1996; 165(5):256-260.
10. Ritchie SA, Phillips D, Broom A, Mackenzie J, Poidinger M, van den Hurk A. Isolation of Japanese encephalitis virus from Cx. annulirostris in Australia. Am J Trop Med Hyg. 1997;56(1):80-84.

11. Ritchie SA, Rochester W. Wind-blown mosquitoes and introduction of Japanese encephalitis into Australia. Emerg Infect Dis. 2001;7(5):900-903.

12. Van Den Hurk AF, Johansen CA, Zborowski P, et al. Flaviviruses isolated from mosquitoes collected during the first recorded outbreak of Japanese encephalitis virus on Cape York Peninsula, Australia. Am J Trop Med Hyg. 2001;64(3-4):125-130.

13. Ritchie SA, van den Hurk AF, Zborowski P, et al. Operational trials of remote mosquito trap systems for Japanese encephalitis virus surveillance in the Torres Strait, Australia. Vector Borne Zoonotic Dis. 2007;7(4): 497-506.

14. Hanna JN, Ritchie SA, Phillips DA, et al. Japanese encephalitis in north Queensland, Australia, 1998. Med J Aust. 1999;170(11):533-536.

15. Mackenzie JS. Emerging viral diseases: an Australian perspective. Emerg Infect Dis. 1999;5(1):1-8.

16. Van Den Hurk AF, Montgomery BL, Northill JA, et al. Short report: the first isolation of Japanese encephalitis virus from mosquitoes collected from mainland Australia. Am J Trop Med Hyg. 2006;75(1): 21-25.

17. Van-den-Hurk AF, Ritchie SA, Johansen CA, Mackenzie JS, Smith GA. Domestic pigs and Japanese encephalitis virus infection, Australia. Emerg Infect Dis. 2008;14(11):1736-1738.

18. Khan AM, Khan AQ, Dobrzynski L, Joshi GP, Myat A. A Japanese encephalitis focus in Bangladesh. J Trop Med Hyg. 1981;84(1): $41-44$.

19. Hossain MJ, Gurley ES, Montgomery S, et al. Hospital-based surveillance for Japanese encephalitis at four sites in Bangladesh, 2003-2005. The American journal of tropical medicine and hygiene. 2010;82(2):344.

20. Paul RC, Rahman M, Gurley ES, et al. A novel low-cost approach to estimate the incidence of Japanese encephalitis in the catchment area of three hospitals in Bangladesh. Am J Trop Med Hyg. 2011;85(2):379-385.

21. Ming CK, Swe T, Thaung U,LwinTT. Recentoutbreaks of Japaneseencephalitis in Burma. Southeast Asian J Trop Med Public Health. 1977;8(1): $113-120$.

22. Swe T, Thein S, Myint MS. Pilot sero-epidemiological survey on Japanese encephalitis in north-western Burma. Biken J. 1979;22(4): $125-129$.

23. Chhour YM, Ruble G, Hong R, et al. Hospital-based diagnosis of hemorrhagic fever, encephalitis, and hepatitis in Cambodian children. Emerg Infect Dis. 2002;8(5):485-489.

24. Srey VH, Sadones H, Ong S, et al. Etiology of encephalitis syndrome among hospitalized children and adults in Takeo, Cambodia, 1999-2000. Am J Trop Med Hyg. 2002;66(2):200-207.

25. Touch S, Hills S, Sokhal B, et al. Epidemiology and burden of disease from Japanese encephalitis in Cambodia: results from two years of sentinel surveillance. Trop Med Int Health. 2009;14(11): 1365-1373.

26. Hills SL, Van Cuong N, Touch S, et al. Disability from Japanese encephalitis in Cambodia and Viet Nam. J Trop Pediatr. 2011;57(4): 241-244.

27. Duong V, Sorn S, Holl D, Rani M, Deubel V, Buchy P. Evidence of Japanese encephalitis virus infections in swine populations in 8 provinces of Cambodia: implications for national Japanese encephalitis vaccination policy. Acta Trop. 2011;120(1-2):146-150.

28. Touch S, Suraratdecha C, Samnang C, et al. A cost-effectiveness analysis of Japanese encephalitis vaccine in Cambodia. Vaccine. 2010;28(29): 4593-4599.

29. Wang H, Li Y, Liang X, Liang G. Japanese encephalitis in mainland China. Jpn J Infect Dis. 2009;62(5):331-336.

30. Zheng Y, Li M, Wang H, Liang G. Japanese encephalitis and Japanese encephalitis virus in mainland China. Rev Med Virol. 2012;5(22): 301-322.

31. Wang LH, Fu SH, Wang HY, et al. Japanese encephalitis outbreak, Yuncheng, China, 2006. Emerg Infect Dis. 2007;13(7):1123-1125. 
32. Gao X, Li X, Li M, et al. Vaccine Strategies for the Control and Prevention of Japanese Encephalitis in Mainland China, 1951-2011. PLoS Negl Trop Dis. 2014;8(8):e3015.

33. Li YX, Li MH, Fu SH, et al. Japanese encephalitis, Tibet, China. Emerg Infect Dis. 2011;17(5):934-936.

34. Li MH, Fu SH, Chen WX, et al. Genotype v Japanese encephalitis virus is emerging. PLoS Negl Trop Dis. 2011;5(7):e1231.

35. Li MH, Fu SH, Chen WX, Wang HY, Cao YX, Liang GD. Molecular characterization of full-length genome of Japanese encephalitis virus genotype V isolated from Tibet, China. Biomed Environ Sci. 2014;27(4): 231-239.

36. Xufang Y, Huanyu W, Shihong F, et al. Etiological spectrum of clinically diagnosed Japanese encephalitis cases reported in Guizhou Province, China, in 2006. J Clin Microbiol. 2010;48(4):1343-1349.

37. Yin Z, Wang H, Yang J, et al. Japanese encephalitis disease burden and clinical features of Japanese encephalitis in four cities in the People's Republic of China. Am J Trop Med Hyg. 2010;83(4):766-773.

38. Wang SP. Japanese encephalitis in Taiwan: A Review of recent studies. Bull World Health Organ. 1964;30:279-284.

39. Tseng HF, Tan HF, Chang CK, Huang WL, Ho WC. Seroepidemiology study of Japanese encephalitis neutralizing antibodies in southern Taiwan: a comparative study between urban city and country townships. Am J Infect Control. 2003;31(7):435-440.

40. Wu YC, Huang YS, Chien LJ, et al. The epidemiology of Japanese encephalitis on Taiwan during 1966-1997. Am J Trop Med Hyg. 1999; 61(1):78-84.

41. Yang SE, Pan MJ, Tseng HF, Liau MY. The efficacy of mouse-brain inactivated Nakayama strain Japanese encephalitis vaccine - results from 30 years experience in Taiwan. Vaccine. 2006;24(14):2669-2673.

42. Shyu WR, Wang YC, Chin C, Chen WJ. Assessment of neutralizing antibodies elicited by a vaccine (Nakayama) strain of Japanese encephalitis virus in Taiwan. Epidemiol Infect. 1997;119(1):79-83.

43. Hsu ST, Chang LC, Lin SY, et al. The effect of vaccination with a live attenuated strain of Japanese encephalitis virus on stillbirths in swine in Taiwan. Bull World Health Organ. 1972;46(4):465-471.

44. Chen KM, Tsai HC, Sy CL, et al. Clinical manifestations of Japanese encephalitis in southern Taiwan. J Microbiol Immunol Infect. 2009; 42(4):296-302.

45. Okuno T, Tseng PT, Liu SY, Hsu SY, Huang CT. Rates of infection with Japanese encephalitis virus of two culicine species of mosquito in Taiwan. Bull World Health Organ. 1971;44(5):599-604.

46. Detels R, Cross JH, Huang WC, Lien JC, Chen S. Japanese encephalitis virus in Northern Taiwan, 1969-1973. Am J Trop Med Hyg. 1976;25(3): 477-485.

47. Rosen L, Lien JC, Lu LC. A longitudinal study of the prevalence of Japanese encephalitis virus in adult and larval Cx. tritaeniorhynchus mosquitoes in northern Taiwan. Am J Trop Med Hyg. 1989;40(5): 557-560.

48. Hammon WM, Tigertt WD, Sather GE, Berge TO, Meiklejohn G. Epidemiologic studies of concurrent virgin epidemics of Japanese B encephalitis and of mumps on Guam, 1947-1948, with subsequent observations including dengue, through 1957. Am J Trop Med Hyg. 1958;7(4):441-467.

49. Edgren DC, Palladino VS, Arnold A. Japanese B and mumps encephalitis: a clinicopathological report of simultaneous outbreaks on the island of Guam. Am J Trop Med Hyg. 1958;7(5):471-480.

50. Reeves WC, Rudnick A. A survey of the mosquitoes of Guam in two periods in 1948 and 1949 and its epidemiological implications. Am J Trop Med Hyg. 1951;31(5):633-658.

51. Smithburn KC, Kerr JA, Gatne PB. Neutralizing antibodies against certain viruses in the sera of residents of India. J Immunol. 1954;72(4):248-257.

52. Kabilan L, Rajendran R, Arunachalam N, et al. Japanese encephalitis in India: an overview. Indian J Pediatr. 2004;71(7):609-615.

53. Tiwari S, Singh RK, Tiwari R, Dhole TN. Japanese encephalitis: a review of the Indian perspective. Braz J Infect Dis. 2012;16(6):564-573.

54. Chakravarty SK, Sarkar JK, Chakravarty MS, et al. The first epidemic of Japanese encephalitis studied in India - virological studies. Indian J Med Res. 1975;63(1):77-82.
55. Dhanda V, Thenmozhi V, Kumar NP, et al. Virus isolation from wildcaught mosquitoes during a Japanese encephalitis outbreak in Kerala in 1996. Indian J Med Res. 1997;106:4-6.

56. Mohan RC, Prasad SR, Rodrigues JJ, Sharma NG, Shaikh BH, Pavri KM. The first laboratory proven outbreak of Japanese encephalitis in Goa. Indian J Med Res. 1983;78:745-750.

57. Sharma SN, Panwar BS. An epidemic of Japanese encephalitis in Haryana in the year 1990. J Commun Dis. 1991;23(3):204-205.

58. Prasad SR, Kumar V, Marwaha RK, Batra KL, Rath RK, Pal SR. An epidemic of encephalitis in Haryana: serological evidence of Japanese encephalitis in a few patients. Indian Pediatr. 1993;30(7): 905-910.

59. Mathur A, Chaturvedi UC, Tandon HO, et al. Japanese encephalitis epidemic in Uttar Pradesh, India during 1978. Indian J Med Res. 1982; 75:161-169.

60. Lawrence J. Japanese encephalitis outbreak in India and Nepal. Euro Surveill. 2005;10(9):E50922-E50924.

61. Mudur G. Japanese encephalitis outbreak kills 1300 children in India. BMJ. 2005;331(7528):1288.

62. Kumar R, Tripathi P, Singh S, Bannerji G. Clinical features in children hospitalized during the 2005 epidemic of Japanese encephalitis in Uttar Pradesh, India. Clin Infect Dis. 2006;43(2):123-131.

63. Phukan AC, Borah PK, Mahanta J. Japanese encephalitis in Assam, northeast India. Southeast Asian J Trop Med Public Health. 2004;35(3) 618-622.

64. Sarkar A, Taraphdar D, Mukhopadhyay SK, Chakrabarti S, Chatterjee S. Serological and molecular diagnosis of Japanese encephalitis reveals an increasing public health problem in the state of West Bengal, India. Trans R Soc Trop Med Hyg. 2012;106(1):15-19.

65. Bandyopadhyay B, Bhattacharyya I, Adhikary S, et al. Incidence of Japanese encephalitis among acute encephalitis syndrome cases in West Bengal, India. Biomed Res Int. 2013;2013:896749.

66. Gajanana A, Thenmozhi V, Samuel PP, Reuben R. A communitybased study of subclinical flavivirus infections in children in an area of Tamil Nadu, India, where Japanese encephalitis is endemic. Bull World Health Organ. 1995;73(2):237-244.

67. Potula R, Badrinath S, Srinivasan S. Japanese encephalitis in and around Pondicherry, South India: a clinical appraisal and prognostic indicators for the outcome. J Trop Pediatr. 2003;49(1):48-53.

68. Kabilan L, Ramesh S, Srinivasan S, Thenmozhi V, Muthukumaravel S, Rajendran R. Hospital- and laboratory-based investigations of hospitalized children with central nervous system-related symptoms to assess Japanese encephalitis virus etiology in Cuddalore District, Tamil Nadu, India. J Clin Microbiol. 2004;42(6):2813-2815.

69. Kabilan L, Vrati S, Ramesh S, et al. Japanese encephalitis virus (JEV) is an important cause of encephalitis among children in Cuddalore district, Tamil Nadu, India. J Clin Virol. 2004;31(2):153-159.

70. Reuben R, Thenmozhi V, Samuel PP, Gajanana A, Mani TR. Mosquito blood feeding patterns as a factor in the epidemiology of Japanese encephalitis in southern India. Am J Trop Med Hyg. 1992;46(6):654-663.

71. Thenmozhi V, Rajendran R, Ayanar K, Manavalan R, Tyagi BK. Long-term study of Japanese encephalitis virus infection in Anopheles subpictus in Cuddalore district, Tamil Nadu, South India. Trop Med Int Health. 2006;11(3):288-293.

72. Mariappan T, Samuel PP, Thenmozhi V, et al. Entomological investigations into an epidemic of Japanese encephalitis (JE) in northern districts of West Bengal, India (2011-2012). Indian J Med Res. 2014;139(5): 754-761.

73. Tewari SC, Thenmozhi V, Arunachalam N, Philip SP, Tyagi BK Desiccated vector mosquitoes used for the surveillance of Japanese encephalitis virus activity in endemic southern India. Trop Med Int Health. 2008;13(2):286-290.

74. Yoshida M, Igarashi A, Suwendra P, et al. The first report on human cases serologically diagnosed as Japanese encephalitis in Indonesia Southeast Asian J Trop Med Public Health. 1999;30(4):698-706.

75. Kari K, Liu W, Gautama K, et al. A hospital-based surveillance for Japanese encephalitis in Bali, Indonesia. BMC Med. 2006;4:8. 
76. Ompusunggu S, Hills SL, Maha MS, et al. Confirmation of Japanese encephalitis as an endemic human disease through sentinel surveillance in Indonesia. Am J Trop Med Hyg. 2008;79(6):963-970.

77. Yamanaka A, Mulyatno KC, Susilowati H, et al. Prevalence of antibodies to Japanese encephalitis virus among pigs in Bali and East Java, Indonesia, 2008. Jpn J Infect Dis. 2010;63(1):58-60.

78. Konishi E, Sakai Y, Kitai Y, Yamanaka A. Prevalence of antibodies to Japanese encephalitis virus among inhabitants in Java Island, Indonesia, with a small pig population. Am J Trop Med Hyg. 2009;80(5):856-861.

79. Arai S, Matsunaga Y, Takasaki T, et al. Japanese encephalitis: surveillance and elimination effort in Japan from 1982 to 2004. Jpn J Infect Dis. 2008;61(5):333-338.

80. Konishi E, Shoda M, Yamamoto S, Arai S, Tanaka-Taya K, Okabe N. Natural infection with Japanese encephalitis virus among inhabitants of Japan: a nationwide survey of antibodies against nonstructural 1 protein. Vaccine. 2006;24(16):3054-3056.

81. Ayukawa R, Fujimoto H, Ayabe M, et al. An unexpected outbreak of Japanese encephalitis in the Chugoku district of Japan, 2002. Jpn J Infect Dis. 2004;57(2):63-66.

82. Saito M, Sunagawa T, Makino Y, et al. Three Japanese encephalitis cases in Okinawa, Japan, 1991. Southeast Asian J Trop Med Public Health. 1999;30(2):277-279.

83. Oya A, Kurane I. Japanese encephalitis for a reference to international travelers. J Travel Med. 2007;14(4):259-268.

84. Konishi E, Suzuki T. Ratios of subclinical to clinical Japanese encephalitis (JE) virus infections in vaccinated populations: evaluation of an inactivated JE vaccine by comparing the ratios with those in unvaccinated populations. Vaccine. 2002;21(1-2):98-107.

85. Konishi E, Shoda M, Kondo T. Analysis of yearly changes in levels of antibodies to Japanese encephalitis virus nonstructural 1 protein in racehorses in central Japan shows high levels of natural virus activity still exist. Vaccine. 2006;24(4):516-524.

86. Matsunaga T, Shoda M, Konishi E. Japanese encephalitis viral infection remains common in Japan. Pediatr Infect Dis J. 2008;27(8):769-770.

87. Konishi E. Status of natural infection with Japanese encephalitis virus in Japan: prevalence of antibodies to the nonstructural 1 protein among humans and horses. Vaccine. 2009;27(50):7129-7130.

88. Konishi E, Kitai Y, Tabei Y, Nishimura K, Harada S. Natural Japanese encephalitis virus infection among humans in west and east Japan shows the need to continue a vaccination program. Vaccine. 2010;28(14): 2664-2670.

89. Konishi E, Shoda M, Kondo T. Prevalence of antibody to Japanese encephalitis virus nonstructural 1 protein among racehorses in Japan: indication of natural infection and need for continuous vaccination. Vaccine. 2004;22(9-10):1097-1103.

90. Tadano M, Kanemura K, Hasegawa H, Makino Y, Fukunaga T. Epidemiological and ecological studies of Japanese encephalitis in Okinawa, subtropical area in Japan. I. Investigations on antibody levels to Japanese encephalitis virus in swine sera and vector mosquito in Okinawa, Miyako and Ishigaki islands. Microbiol Immunol. 1994;38(2): $117-122$.

91. Sugiura T, Shimada K. Seroepizootiological survey of Japanese encephalitis virus and Getah virus in regional horse race tracks from 1991 to 1997 in Japan. J Vet Med Sci. 1999;61(8):877-881.

92. Nidaira M, Taira K, Itokazu K, et al. Survey of the antibody against Japanese encephalitis virus in Ryukyu wild boars (Sus scrofa riukiuanus) in Okinawa, Japan. Jpn J Infect Dis. 2007;60(5): 309-311.

93. Ohno Y, Sato H, Suzuki K, et al. Detection of antibodies against Japanese encephalitis virus in raccoons, raccoon dogs and wild boars in Japan. J Vet Med Sci. 2009;71(8):1035-1039.

94. Hamano M, Lim CK, Takagi H, et al. Detection of antibodies to Japanese encephalitis virus in the wild boars in Hiroshima prefecture, Japan. Epidemiol Infect. 2007;135(6):974-977.

95. Phonsavanh Vongxay YMKK, Mika Saito ATF. Seroepidemiological study of arbovirus infections in Khammouane Province, Lao PDR. V; 1995;15:19-22.
96. Hiscox A, Winter $\mathrm{CH}$, Vongphrachanh $\mathrm{P}$, et al. Serological investigations of flavivirus prevalence in Khammouane Province, Lao People's Democratic Republic, 2007-2008. Am J Trop Med Hyg. 2010;83(5): 1166-1169.

97. Vallee J, Dubot-Peres A, Ounaphom P, Sayavong C, Bryant JE, Gonzalez JP. Spatial distribution and risk factors of dengue and Japanese encephalitis virus infection in urban settings: the case of Vientiane, Lao PDR. Trop Med Int Health. 2009;14(9):1134-1142.

98. Moore CE, Blacksell SD, Taojaikong T, et al. A prospective assessment of the accuracy of commercial IgM ELISAs in diagnosis of Japanese encephalitis virus infections in patients with suspected central nervous system infections in Laos. Am J Trop Med Hyg. 2012;87(1):171-178.

99. Aubry F, Vongsouvath M, Nougairede A, et al. Complete Genome of a Genotype I Japanese Encephalitis Virus Isolated from a Patient with Encephalitis in Vientiane, Lao PDR. Genome Announc. 2013;1(1):e00157-12.

100. Easton A. Outbreak of Japanese encephalitis hits Malaysia. BMJ. 1999;318(7188):893.

101. Wong SC, Ooi MH, Abdullah AR, et al. A decade of Japanese encephalitis surveillance in Sarawak, Malaysia: 1997-2006. Trop Med Int Health. 2008;13(1):52-55.

102. Ooi MH, Lewthwaite P, Lai BF, et al. The epidemiology, clinical features, and long-term prognosis of Japanese encephalitis in central sarawak, malaysia, 1997-2005. Clin Infect Dis. 2008;47(4):458-468.

103. Impoinvil DE, Ooi MH, Diggle PJ, et al. The effect of vaccination coverage and climate on Japanese encephalitis in Sarawak, Malaysia. PLoS Negl Trop Dis. 2013;7(8):e2334.

104. Vythilingam I, Tan SB, Krishnasamy M. Susceptibility of Cx. sitiens to Japanese encephalitis virus in peninsular Malaysia. Trop Med Int Health. 2002;7(6):539-540.

105. Bista MB, Shrestha JM. Epidemiological situation of Japanese encephalitis in Nepal. JNMA J Nepal Med Assoc. 2005;44(158):51-56.

106. Bhattachan A, Amatya S, Sedai TR, Upreti SR, Partridge J. Japanese encephalitis in hill and mountain districts, Nepal. Emerg Infect Dis. 2009;15(10):1691-1692.

107. Wakai S. Scourge of Japanese encephalitis in southwestern Nepal. Lancet. 1998;351(9104):759.

108. Wierzba TF, Ghimire P, Malla S, et al. Laboratory-based Japanese encephalitis surveillance in Nepal and the implications for a national immunization strategy. Am J Trop Med Hyg. 2008;78(6): 1002-1006.

109. Dumre SP, Shakya G, Na-Bangchang K, et al. Dengue virus and Japanese encephalitis virus epidemiological shifts in Nepal: a case of opposing trends. Am J Trop Med Hyg. 2013;88(4):677-680.

110. Upreti SR, Janusz KB, Schluter WW, et al. Estimation of the impact of a Japanese encephalitis immunization program with live, attenuated SA 14-14-2 vaccine in Nepal. Am J Trop Med Hyg. 2013;88(3): 464-468.

111. Pant GR, Lunt RA, Rootes CL, Daniels PW. Serological evidence for Japanese encephalitis and West Nile viruses in domestic animals of Nepal. Comp Immunol Microbiol Infect Dis. 2006;29(2-3):166-175.

112. Dhakal S, Stephen C, Ale A, Joshi DD. Knowledge and practices of pig farmers regarding Japanese encephalitis in Kathmandu, Nepal. Zoonoses Public Health. 2012;59(8):568-574.

113. Thakur KK, Pant GR, Wang L, et al. Seroprevalence of Japanese encephalitis virus and risk factors associated with seropositivity in pigs in four mountain districts in Nepal. Zoonoses Public Health. 2012;59(6):393-400.

114. Dhakal S, Joshi DD, Ale A, et al. Regional variation in pig farmer awareness and actions regarding Japanese encephalitis in Nepal: implications for public health education. PLoS One. 2014;9(1):e85399.

115. Darwish MA, Hoogstraal H, Roberts TJ, Ahmed IP, Omar F. A seroepidemiological survey for certain arboviruses (Togaviridae) in Pakistan. Trans R Soc Trop Med Hyg. 1983;77(4):442-445.

116. Igarashi A, Tanaka M, Morita K, et al. Detection of west Nile and Japanese encephalitis viral genome sequences in cerebrospinal fluid from acute encephalitis cases in Karachi, Pakistan. Microbiol Immunol. 1994;38(10):827-830 
117. Johansen CA, van den Hurk AF, Ritchie SA, et al. Isolation of Japanese encephalitis virus from mosquitoes (Diptera: Culicidae) collected in the Western Province of Papua New Guinea, 1997-1998. Am J Trop Med Hyg. 2000;62(5):631-638.

118. Hanson JP, Taylor CT, Richards AR, Smith IL, Boutlis CS. Japanese encephalitis acquired near Port Moresby: implications for residents and travellers to Papua New Guinea. Med J Aust. 2004;181(5):282-283.

119. Trosper JH, Ksiazek TG, Cross JH. Isolation of Japanese encephalitis virus from the Republic of the Philippines. Trans $R$ Soc Trop Med Hyg. 1980;74(3):292-295.

120. Barzaga NG. A review of Japanese encephalitis cases in the Philippines (1972-1985). Southeast Asian J Trop Med Public Health. 1989;20(4):587-592.

121. Natividad FF, Daroy ML, Alonzo MT, Matias RR, Suarez LA, Inoue S. Use of IgM-capture ELISA for confirmation of Japanese encephalitis infections in the Philippines. Southeast Asian J Trop Med Public Health. 2006;37 Suppl 3:136-139.

122. Zhi C. Arbovirus and Arbovirus diseases. Heilongjiang Science and Technology Press; 1991:151

123. Pogodina VV, Bochkova NG, Leshchinskaia EV, Levina LS. Japanese encephalitis in citizens of Russia who travel abroad. Vopr Virusol. 1996;41(1):8-11.

124. Paul WS, Moore PS, Karabatsos N, et al. Outbreak of Japanese encephalitis on the island of Saipan, 1990. J Infect Dis. 1993;167(5):1053-1058.

125. Mitchell CJ, Savage HM, Smith GC, Flood SP, Castro LT, Roppul M Japanese encephalitis on Saipan: a survey of suspected mosquito vectors. Am J Trop Med Hyg. 1993;48(4):585-590.

126. See E, Tan HC, Wang D, Ooi EE, Lee MA. Presence of hemagglutination inhibition and neutralization antibodies to Japanese encephalitis virus in wild pigs on an offshore island in Singapore. Acta Trop. 2002;81(3):233-236.

127. Ting SH, Tan HC, Wong WK, Ng ML, Chan SH, Ooi EE. Seroepidemiology of neutralizing antibodies to Japanese encephalitis virus in Singapore: continued transmission despite abolishment of pig farming? Acta Trop. 2004;92(3):187-191.

128. Koh YL, Tan BH, Loh JJ, Ooi EE, Su SY, Hsu LY. Japanese encephalitis, Singapore. Emerg Infect Dis. 2006;12(3):525-526.

129. Chan YC, Loh TF. Isolation of Japanese encephalitis virus from the blood of a child in Singapore. Am J Trop Med Hyg. 1966;15(4) 567-572.

130. Yang DK, Kim BH, Kweon CH, Kwon JH, Lim SI, Han HR. Biophysical characterization of Japanese encephalitis virus (KV1899) isolated from pigs in Korea. $J$ Vet Sci. 2004;5(2):125-130.

131. Lee DW, Choe YJ, Kim JH, et al. Epidemiology of Japanese encephalitis in South Korea, 2007-2010. Int J Infect Dis. 2012;16(6):e448-e452.

132. Joo CY, Wada Y. Seasonal prevalence of the vector mosquitoes of Japanese encephalitis virus in Kyungpook Province, Korea. Kisaengchunghak Chapchi. 1985;23(1):139-150.

133. Baik DH, Joo CY. Epidemio-entomological survey of Japanese encephalitis in Korea. Kisaengchunghak Chapchi. 1991;29(1):67-85.

134. Lim SI, Kweon CH, Tark DS, Kim SH, Yang DK. Sero-survey on Aino, Akabane, Chuzan, bovine ephemeral fever and Japanese encephalitis virus of cattle and swine in Korea. $J$ Vet Sci. 2007;8(1):45-49.

135. Yang DK, Kweon CH, Kim BH, et al. The seroprevalence of Japanese encephalitis virus in goats raised in Korea. J Vet Sci. 2007;8(2):197-199.

136. Yang DK, Kim BH, Kweon CH, et al. Serosurveillance for Japanese encephalitis, Akabane, and Aino viruses for Thoroughbred horses in Korea. J Vet Sci. 2008;9(4):381-385.

137. Yang DK, Oh YI, Kim HR, et al. Serosurveillance for Japanese encephalitis virus in wild birds captured in Korea. J Vet Sci. 2011;12(4):373-377.

138. De Alwis KN, Abeysinghe MR, Wickramesinghe AR, Wijesinghe PR. A cohort event monitoring to determine the adverse events following administration of mouse brain derived, inactivated Japanese Encephalitis vaccine in an endemic district in Sri Lanka. Vaccine. 2014;32(8):924-930.

139. Peiris JS, Amerasinghe FP, Amerasinghe PH, Ratnayake CB, Karunaratne SH, Tsai TF. Japanese encephalitis in Sri Lanka - the study of an epidemic: vector incrimination, porcine infection and human disease. Trans R Soc Trop Med Hyg. 1992;86(3):307-313.
140. Wijesinghe PR, Abeysinghe MR, Yoksan S, et al. Safety and immunogenicity of live-attenuated Japanese encephalitis SA 14-14-2 vaccine co-administered with measles vaccine in 9-month-old infants in Sri Lanka. Vaccine. 2014.

141. Thongcharoen P. Japanese encephalitis in Thailand. JMed Assoc Thai. 1985;68(10):534-545.

142. Chunsuttiwat S. Japanese encephalitis in Thailand. Southeast Asian J Trop Med Public Health.1989;20(4):593-597.

143. Olsen SJ, Supawat K, Campbell AP, et al. Japanese encephalitis virus remains an important cause of encephalitis in Thailand. Int J Infect Dis. 2010;14(10):e888-e892.

144. Muangchana C, Henprasertthae N, Nurach K, et al. Effectiveness of mouse brain-derived inactivated Japanese encephalitis vaccine in Thai National Immunization Program: a case-control study. Vaccine. 2012;30(2):361-367.

145. Yen NT, Duffy MR, Hong NM, Hien NT, Fischer M, Hills SL. Surveillance for Japanese encephalitis in Vietnam, 1998-2007. Am J Trop Med Hyg. 2010;83(4):816-819.

146. Lowry PW, Truong DH, Hinh LD, et al. Japanese encephalitis among hospitalized pediatric and adult patients with acute encephalitis syndrome in Hanoi, Vietnam 1995. Am J Trop Med Hyg. 1998;58(3):324-329.

147. Takamatsu Y, Uchida L, Nga PT, et al. An approach for differentiating echovirus 30 and Japanese encephalitis virus infections in acute meningitis/encephalitis: a retrospective study of 103 cases in Vietnam. Virol J. 2013;10:280.

148. Lewis L, Taylor HG, Et A. Japanese B encephalitis; clinical observations in an outbreak on Okinawa Shima. Arch Neurol Psychiatry. 1947;57(4):430-463

149. Chen WR, Tesh RB, Rico-Hesse R. Genetic variation of Japanese encephalitis virus in nature. J Gen Virol. 1990;71 (Pt 12):2915-2922.

150. Chen WR, Rico-Hesse R, Tesh RB. A new genotype of Japanese encephalitis virus from Indonesia. Am J Trop Med Hyg. 1992;47(1):61-69.

151. Uchil PD, Satchidanandam V. Phylogenetic analysis of Japanese encephalitis virus: envelope gene based analysis reveals a fifth genotype, geographic clustering, and multiple introductions of the virus into the Indian subcontinent. Am J Trop Med Hyg. 2001;65(3):242-251.

152. Solomon T, Ni H, Beasley DW, Ekkelenkamp M, Cardosa MJ, Barrett AD. Origin and evolution of Japanese encephalitis virus in southeast Asia. J Virol. 2003;77(5):3091-3098.

153. Pan XL, Liu H, Wang HY, et al. Emergence of genotype I of Japanese encephalitis virus as the dominant genotype in Asia. $J$ Virol. 2011;85(19):9847-9853.

154. Gao X, Liu H, Wang H, Fu S, Guo Z, Liang G. Southernmost Asia is the source of Japanese encephalitis virus (genotype 1) diversity from which the viruses disperse and evolve throughout Asia. PLoS Negl Trop Dis. 2013;7(9):e2459.

155. Wang HY, Takasaki T, Fu SH, et al. Molecular epidemiological analysis of Japanese encephalitis virus in China. J Gen Virol. 2007 88(Pt 3):885-894.

156. Wang J, Zhang $\mathrm{H}, \mathrm{Fu} \mathrm{S}$, et al. Isolation of kyasanur forest disease virus from febrile patient, yunnan, China. Emerg Infect Dis. 2009;15(2): 326-328.

157. Wang L, Fu S, Zhang H, et al. Identification and isolation of Genotype-I Japanese encephalitis virus from encephalitis patients. Virol J. 2010; 7:345.

158. Cao QS, Li XM, Zhu QY, Wang DD, Chen HC, Qian P. Isolation and molecular characterization of genotype 1 Japanese encephalitis virus, SX09S-01, from pigs in China. Virol J. 2011;8:472.

159. Jan LR, Yueh YY, Wu YC, Horng CB, Wang GR. Genetic variation of Japanese encephalitis virus in Taiwan. Am J Trop Med Hyg. 2000; 62(4):446-452.

160. Huang JH, Lin TH, Teng HJ, et al. Molecular epidemiology of Japanese encephalitis virus, Taiwan. Emerg Infect Dis. 2010;16(5): 876-878.

161. Chen YY, Fan YC, Tu WC, et al. Japanese encephalitis virus genotype replacement, Taiwan, 2009-2010. Emerg Infect Dis. 2011;17(12): 2354-2356. 
162. Ma SP, Arakaki S, Makino Y, Fukunaga T. Molecular epidemiology of Japanese encephalitis virus in Okinawa. Microbiol Immunol. 1996;40(11):847-855.

163. Takegami T, Ishak H, Miyamoto C, Shirai Y, Kamimura K. Isolation and molecular comparison of Japanese encephalitis virus in Ishikawa, Japan. Jpn J Infect Dis. 2000;53(4):178-179.

164. Ma SP, Yoshida Y, Makino Y, Tadano M, Ono T, Ogawa M. Short report: a major genotype of Japanese encephalitis virus currently circulating in Japan. Am J Trop Med Hyg. 2003;69(2):151-154.

165. Kuwayama M, Ito M, Takao S, et al. Japanese encephalitis virus in meningitis patients, Japan. Emerg Infect Dis. 2005;11(3):471-473.

166. Yoshida Y, Tabei Y, Hasegawa M, Nagashima M, Morozumi S. Genotypic analysis of Japanese encephalitis virus strains isolated from swine in Tokyo, Japan. Jpn J Infect Dis. 2005;58(4):259-261.

167. Yamanaka T, Tsujimura K, Kondo T, et al. Isolation and genetic analysis of Japanese encephalitis virus from a diseased horse in Japan. $J$ Vet Med Sci. 2006;68(3):293-295.

168. Saito M, Taira K, Itokazu K, Mori N. Recent change of the antigenicity and genotype of Japanese encephalitis viruses distributed on Okinawa Island, Japan. Am J Trop Med Hyg. 2007;77(4):737-746.

169. Nerome R, Tajima S, Takasaki T, et al. Molecular epidemiological analyses of Japanese encephalitis virus isolates from swine in Japan from 2002 to 2004. J Gen Virol. 2007;88(Pt 10):2762-2768.

170. Nidaira M, Taira K, Itokazu K, et al. Detection of Japanese encephalitis virus genome in Ryukyu wild boars (Sus scrofa riukiuanus) in Okinawa, Japan. Jpn J Infect Dis. 2008;61(2):164-165.

171. Nabeshima T, Loan HT, Inoue S, et al. Evidence of frequent introductions of Japanese encephalitis virus from south-east Asia and continental east Asia to Japan. J Gen Virol. 2009;90(Pt 4):827-832.

172. Nidaira M, Taira K, Okano S, et al. Survey of Japanese encephalitis virus in pigs on Miyako, Ishigaki, Kume, and Yonaguni Islands in Okinawa, Japan. Jpn J Infect Dis. 2009;62(3):220-224.

173. Tang WF, Ogawa M, Eshita Y, Aono H, Makino Y. Molecular evolution of Japanese encephalitis virus isolates from swine in Oita, Japan during 1980-2009. Infect Genet Evol. 2010;10(2):329-336.

174. Obara M, Yamauchi T, Watanabe M, et al. Continuity and change of Japanese encephalitis virus in Toyama Prefecture, Japan. Am J Trop Med Hyg. 2011;84(5):695-708.

175. Yang DK, Kim BH, Kweon CH, Kwon JH, Lim SI, Han HR. Molecular characterization of full-length genome of Japanese encephalitis virus (KV1899) isolated from pigs in Korea. J Vet Sci. 2004;5(3):197-205.
176. Yun SM, Cho JE, Ju YR, et al. Molecular epidemiology of Japanese encephalitis virus circulating in South Korea, 1983-2005. Virol J. 2010;7:127.

177. Takhampunya R, Kim HC, Tippayachai B, et al. Emergence of Japanese encephalitis virus genotype $\mathrm{V}$ in the Republic of Korea. Virol J. 2011;8:449.

178. Seo HJ, Kim HC, Klein TA, et al. Molecular detection and genotyping of Japanese encephalitis virus in mosquitoes during a 2010 outbreak in the Republic of Korea. PLoS One. 2013;8(2):e55165.

179. Nitatpattana N, Dubot-Peres A, Gouilh MA, et al. Change in Japanese encephalitis virus distribution, Thailand. Emerg Infect Dis. 2008; 14(11):1762-1765.

180. Fulmali PV, Sapkal GN, Athawale S, Gore MM, Mishra AC, Bondre VP. Introduction of Japanese encephalitis virus genotype I, India. Emerg Infect Dis. 2011;17(2):319-321.

181. Sarkar A, Taraphdar D, Mukhopadhyay SK, Chakrabarti S, Chatterjee S. Molecular evidence for the occurrence of Japanese encephalitis virus genotype I and III infection associated with acute encephalitis in patients of West Bengal, India, 2010. Virol J. 2012;9:271.

182. Gulati BR, Singha H, Singh BK, Virmani N, Kumar S, Singh RK. Isolation and genetic characterization of Japanese encephalitis virus from equines in India. $J$ Vet Sci. 2012;13(2):111-118.

183. Singha H, Gulati BR, Kumar P, Singh BK, Virmani N, Singh RK. Complete genome sequence analysis of Japanese encephalitis virus isolated from a horse in India. Arch Virol. 2013;158(1):113-122.

184. Huong VT, Ha DQ, Deubel V. Genetic study of Japanese encephalitis viruses from Vietnam. Am J Trop Med Hyg. 1993;49(5):538-544.

185. Nga PT, Del CPM, Cuong VD, et al. Shift in Japanese encephalitis virus (JEV) genotype circulating in northern Vietnam: implications for frequent introductions of JEV from Southeast Asia to East Asia. J Gen Virol. 2004;85(Pt 6):1625-1631.

186. Kuwata R, Nga PT, Yen NT, et al. Surveillance of Japanese encephalitis virus infection in mosquitoes in Vietnam from 2006 to 2008. Am J Trop Med Hyg. 2013;88(4):681-688.

187. Lindahl JF, Stahl K, Chirico J, Boqvist S, Thu HT, Magnusson U. Circulation of Japanese encephalitis virus in pigs and mosquito vectors within Can Tho city, Vietnam. PLoS Negl Trop Dis. 2013;7(4):e2153.

188. Liu X, Yu Y, Li M, et al. Study on the protective efficacy of SA14-14-2 attenuated Japanese encephalitis against different JE virus isolates circulating in China. Vaccine. 2011;29(11):2127-2130.
Therapeutics and Clinical Risk Management

\section{Publish your work in this journal}

Therapeutics and Clinical Risk Management is an international, peerreviewed journal of clinical therapeutics and risk management, focusing on concise rapid reporting of clinical studies in all therapeutic areas, outcomes, safety, and programs for the effective, safe, and sustained use of medicines. This journal is indexed on PubMed Central, CAS,

\section{Dovepress}

EMBase, Scopus and the Elsevier Bibliographic databases. The manuscript management system is completely online and includes a very quick and fair peer-review system, which is all easy to use. Visit http://www.dovepress.com/testimonials.php to read real quotes from published authors. 